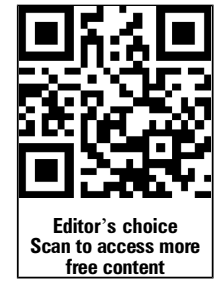

- Additional material is published online only. To view please visit the journal online (http://dx.doi.org/10.1136/ jnnp-2013-305888).

For numbered affiliations see end of article.

\section{Correspondence to} Dr J Chataway, Department of Neuroinflammation, Queen Square Multiple Sclerosis Centre National Hospital for Neurology \& Neurosurgery and University College London Institute of Neurology, Queen Square, London WC1N 3BG, UK; jeremy.chataway@uclh.nhs.uk

Received 19 September 2013 Revised 4 November 2013 Accepted 19 November 2013 Published Online First 19 December 2013

\section{(1) cossmatk}

To cite: Ahmed RM, Murphy E, Davagnanam I, et al. J Neurol Neurosurg Psychiatry 2014;85: 770-781.

\title{
A practical approach to diagnosing adult onset leukodystrophies
}

\author{
R M Ahmed, ${ }_{1}^{1}$ E Murphy, ${ }_{1}{ }^{2}$ D Davagnanam, ${ }^{3}$ M Parton, ${ }_{1}^{4} \mathrm{~J} \mathrm{M} \mathrm{Schott,}{ }^{1}$ C J Mummery, \\ J D Rohrer, ${ }^{1}$ R H Lachmann, ${ }^{2}$ H Houlden, ${ }^{5}$ N C Fox, ${ }^{1}$ J Chataway ${ }^{6}$
}

\section{INTRODUCTION}

The term leukodystrophy refers to a group of conditions that are inherited and involve the progressive destruction or loss of previously acquired myelin. ${ }^{1}$ The most commonly reported of these disorders have a metabolic origin and are associated with abnormalities on specialist biochemical testing. Recently, a number of conditions caused by genes coding for proteins not directly involved in metabolic pathways and for which the diagnosis relies directly on gene analysis have also been described. In clinical practice, distinguishing 'classical' inherited leukodystrophies from other causes of white matter disease, including vascular and inflammatory disorders, may not always be straightforward.

Although individually rare, with no single condition having a prevalence of $>1$ in 20000 , the reported prevalence of adult onset leukodystrophies is rising. This is likely to be related to the increased use of brain MRI and new genetic insights. Collectively their incidence may rival that of multiple sclerosis (MS). ${ }^{2}$ Nonetheless, the rarity of each condition and the wide differential means that diagnosis can be challenging and most clinicians will lack experience in the area. Currently, a significant proportion of individuals may remain without a precise diagnosis despite intensive investigations.

Much has been written in the paediatric literature about leukodystrophies, ${ }^{3}$ but the adult neurologist, with a new case, is often left with an extensive and detailed table of rare disorders to consider, without an obvious diagnostic pathway to follow. In addition, leukodystrophies that classically present in infancy or childhood may have a very different or attenuated clinical presentation in adulthood, making diagnostic features less familiar. In this review, taking a clinical case as a starting point, we address:

- the most commonly presenting leukodystrophies in adults

- their clinical presentations

- MRI patterns for specific leukodystrophies

- how to investigate leukodystrophies in an adult

- current and future treatment possibilities.

Table 1 summarises the most frequent of the inherited leukodystrophies that have been reported to present in adulthood (age of onset of $>16$ years). This list is not exhaustive and almost certainly underestimates the true numbers-with more widespread access to genetic testing it is likely that the list of potential diagnoses and actual prevalences will continue to increase.

\section{CASE STUDY}

A middle aged patient presented to an MS clinic with a 2-year history of progressive gait and cognitive difficulties. Two years earlier, the patient had noted dragging of the right leg, difficulty controlling the leg and had had several falls. One year prior, clumsiness and weakness in the right hand had been noted, as well as word finding difficulties, slowness of thought, problems with episodic memory and that their writing and spelling had deteriorated. The patient had a past history of sciatica and long standing depression. The patient's mother had died at 65 years of age after a 5 -year decline in gait and cognitive function, with MRI brain showing generalised cerebral atrophy and patchy signal change in the peri-ventricular white matter. The mother had been given a diagnosis of vascular dementia. There was no other family history of neurological or psychiatric illness.

On examination, the patient had broken smooth pursuit eye movements and hypometric saccades. The cranial nerves were intact. The upper limb examination was normal. The lower limb examination showed increased tone and power of $4 / 5$ on the right, with a pyramidal pattern of weakness. The reflexes were brisk throughout, with equivocal plantar responses. The gait was apraxic. On cognitive testing she scored 22/30 on the Mini-Mental State Examination. On neuropsychometric testing, there was evidence for generalised cognitive decline with marked impairments on tests sensitive to frontal and parietal lobe functions.

MRI brain (see online supplementary figure S1) showed extensive white matter change predominantly affecting the frontal lobes with involvement and thinning of the corpus callosum.

What is the differential diagnosis and which initial investigations should be performed? With this symptom complex and widespread white matter change on MRI, there are a number of acquired conditions that need to be excluded before an inherited leukodystrophy is considered. These include inflammatory, autoimmune, infectious, neoplastic, metabolic, drug and toxic causes. Suggested initial (Round 1) investigations are outlined in online supplementary table S1. A very rapid onset and progression over months is much more likely to be acquired than genetic, though cerebral adrenoleukodystrophy (ALD) can present abruptly. 


\begin{tabular}{|c|c|c|c|c|c|c|}
\hline Disorder & Age of onset & Prevalence of adult disease & Ethnic predilection & Inheritance & Useful investigation(s) & Gene(s) \\
\hline $\begin{array}{l}X \text { linked adrenoleukodystrophy } \\
\text { adrenomyeloneuropathy (ALD/ } \\
\text { AMN) }^{4} 5\end{array}$ & Childhood to adulthood & $\begin{array}{l}\text { Up to } 40 / \text { million, adult cerebral ALD } \\
\text { accounts for } 5 \% \text { of cases; } 15 \%-20 \% \text { of } \\
\text { heterozygote women are symptomatic }\end{array}$ & & $\begin{array}{l}\text { X linked. Female } \\
\text { carriers can develop } \\
\text { AMN/spastic } \\
\text { paraparesis }\end{array}$ & Very long chain fatty acid levels & $A B C D 1$ \\
\hline $\begin{array}{l}\text { Cerebral autosomal dominant } \\
\text { arteriopathy with subcortical infarcts } \\
\text { and leukoencephalopathy } \\
\text { (CADASIL) } \\
\text { (C* }\end{array}$ & $\begin{array}{l}\text { Migraine: mean } 30 \text { years } \\
\text { (range } 6 \text { - } 48 \text { years). } \\
\text { Ischaemic events: mean } \\
50 \text { years (range } 20- \\
70 \text { years) }\end{array}$ & 10-40/million & & $A D$ and sporadic & Electron microscopy of skin biopsy & NOTCH3 \\
\hline $\begin{array}{l}\text { Globoid cell leukodystrophy (Krabbe } \\
\text { disease) }\end{array}$ & Up to 60 years & $10 /$ million, $10 \%$ adult onset & & AR & $\begin{array}{l}\text { Galactocerebrosidase (GALC) enzyme activity } \\
\text { (leukocytes/fibroblasts) }\end{array}$ & $\begin{array}{l}\text { GALC; } \\
\text { PSAP }\end{array}$ \\
\hline $\begin{array}{l}\text { Metachromatic leukodystrophy } \\
(\text { MLD })^{10}\end{array}$ & Up to 70 years & $2 /$ million, $20 \%$ adult onset & & AR & $\begin{array}{l}\text { Arylsulfatase A (ARSA) enzyme activity } \\
\text { (leukocytes/fibroblasts)† }\end{array}$ & $\begin{array}{l}\text { ARSA; } \\
\text { PSAP }\end{array}$ \\
\hline $\begin{array}{l}\text { Cerebrotendinous xanthomatosis } \\
\left({ }^{(C T X}\right)^{8} 11\end{array}$ & Juvenile to adulthood & $2 /$ million & & AR & Sterol profile. Urine bile alcohols & CYP27A1 \\
\hline Mitochondrial disorders ${ }^{12-14 *}$ & $\begin{array}{l}\text { Childhood and adulthood } \\
\text { —any age }\end{array}$ & $\begin{array}{l}\text { Total prevalence } 100-165 / \text { million, } \\
\text { prevalence of leukoencephalopathy in } \\
\text { adults is not known, paediatric } \\
\text { literature suggests it is common }\end{array}$ & & Maternal, $A D, A R$ & $\begin{array}{l}\text { Lactate (blood/CSF). Mitochondrial respiratory } \\
\text { chain enzyme activity }\end{array}$ & Various \\
\hline $\begin{array}{l}\text { Hereditary diffuse } \\
\text { leukoencephalopathy with } \\
\text { neuroaxonal spheroids (HDLS) }\end{array}$ & $\begin{array}{l}\text { Mean } 40 \text { years (range } 15- \\
78 \text { years) }\end{array}$ & $\begin{array}{l}52 \text { cases described in literature, } \\
\text { incidence increasing with recent } \\
\text { discovery of CSF1R gene }\end{array}$ & & $A D$ and sporadic & $\begin{array}{l}\text { Characteristic brain biopsy findings (now } \\
\text { superseded by molecular genetic testing) }\end{array}$ & CSFR1 \\
\hline $\begin{array}{l}\text { Adult polyglucosan body disease } \\
\text { (APBD) }^{16}\end{array}$ & $40-60$ years & 47 cases & Ashkenazi Jewish & AR & $\begin{array}{l}\text { Sural nerve biopsy. Glycogen brancher enzyme } \\
\text { (GBE) activity (fibroblasts) }\end{array}$ & GBE1 \\
\hline Alexander disease ${ }^{17}$ & $12-62$ years & 36 cases & & $A D$ and sporadic & $\begin{array}{l}\text { Characteristic brain biopsy findings (now } \\
\text { superseded by molecular genetic testing) }\end{array}$ & GFAP \\
\hline $\begin{array}{l}\text { Adult onset autosomal dominant } \\
\text { leukodystrophy (ADLD) })^{18} 19\end{array}$ & $30-50$ years & $\begin{array}{l}\text { Unknown: at least } 27 \text { cases reported in } \\
\text { literature }\end{array}$ & & $A D$ & & LMNB1 \\
\hline 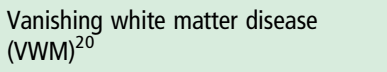 & $\begin{array}{l}\text { Mean } 30 \text { years (range } 16- \\
62 \text { years) }\end{array}$ & $\begin{array}{l}177 \text { cases in total, } 25 \text { with onset } \\
>16 \text { years }\end{array}$ & & AR & & elF2B 1-5 \\
\hline $\begin{array}{l}\text { Cerebral autosomal recessive } \\
\text { arteriopathy with subcortical infarcts } \\
\text { and leukoencephalopathy } \\
\text { (CARASIL) }^{21 *}\end{array}$ & $20-50$ years & $\begin{array}{l}\text { Unknown, thought to be rare, } 50 \text { cases } \\
\text { described thus far }\end{array}$ & $\begin{array}{l}\text { Most reported cases in Japan } \\
\text { and China }\end{array}$ & AR & $\begin{array}{l}\text { On brain pathology, CARASIL is characterised by } \\
\text { intense arteriolosclerosis without the deposition } \\
\text { of granular osmiophilic materials in small arteries } \\
\text { and arterioles that is seen in CADASIL }\end{array}$ & HTRA1 \\
\hline $\begin{array}{l}\text { Hexosaminidase A (HEX A) deficiency } \\
\text { (GM2 gangliosidosis, adult onset } \\
\text { Tay-Sachs disease) }\end{array}$ & $20-40$ years & Small case series & $64 \%$ Jewish origin & AR & $\beta$-HEX A enzymatic activity (leukocytes) & HEXA \\
\hline $\begin{array}{l}\text { Megalencephalic } \\
\text { leukoencephalopathy with subcortical } \\
\text { cysts (MLC) }\end{array}$ & 6 months -50 years & 11 cases aged $>20$ years & Asian-Indian, Turkish & AR & & $\begin{array}{l}\text { MLC1; } \\
\text { HEPACAM }\end{array}$ \\
\hline MTHFR deficiency ${ }^{24}$ & Any age & Limited case reports & & AR & Plasma amino acid profile & MTHFR \\
\hline$\alpha$-Mannosidosis ${ }^{25}$ & $\begin{array}{l}\text { Adolescence, but severe } \\
\text { ataxia } 30-40 \text { years }\end{array}$ & Limited case reports & & AR & $\begin{array}{l}\text { Urine oligosaccharides. Vacuolated lymphocytes. } \\
\alpha \text {-Mannosidase enzyme activity (leukocytes) }\end{array}$ & MAN2B1 \\
\hline Mucolipidosis type IV ${ }^{8} 26$ & $\begin{array}{l}\text { Usually infant childhood, } 1 \\
\text { case onset } 16 \text { years }{ }^{14}\end{array}$ & $\begin{array}{l}\text { Late onset reported due to attenuated } \\
\text { phenotype }\end{array}$ & Ashkenazi Jewish & AR & & MCOLN1 \\
\hline Adult sialidosis ${ }^{27}$ & $\begin{array}{l}\text { Usually childhood, but can } \\
\text { be } 20-30 \text { years }\end{array}$ & Limited case reports & Finnish & AR & $\begin{array}{l}\text { Urine oligosaccharides. Vacuolated lymphocytes. } \\
\alpha \text {-Neuroaminidase enzyme activity (fibroblasts) }\end{array}$ & SLC17A5 \\
\hline
\end{tabular}

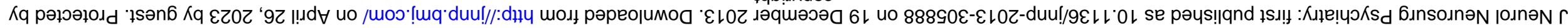


Table 1 Continued

\begin{tabular}{|c|c|c|c|c|c|c|}
\hline Disorder & Age of onset & Prevalence of adult disease & Ethnic predilection & Inheritance & Useful investigation(s) & Gene(s) \\
\hline Organic acidurias ${ }^{28-31}$ & Adolescence to adulthood & Limited case reports & & AR & Urine organic acid profile (UOA) & \\
\hline 1) Canavan disease & & & & & $\begin{array}{l}\uparrow \mathrm{N} \text {-acetylaspartic acid (UOA). Aspartoacylase } \\
\text { enzyme activity (fibroblasts) }\end{array}$ & ASPA \\
\hline 2) Glutaricacidemia type 1 & & & & & $\begin{array}{l}\uparrow \text { Glutaric acid, } 3-\mathrm{OH} \text {-glutaric acid (UOA). } \\
\text { Acylcarnitine profile }\end{array}$ & GCDH \\
\hline 3) L-2-hydroxyglutaric aciduria & & & & & $\uparrow 2$-Hydroxyglutaric acid (UOA). $\uparrow$ Lysine (CSF) & L2HGDH \\
\hline 4) 3-Methylglutaconic aciduria type 1 & & & & & $\begin{array}{l}\uparrow 3 \text {-Methylglutaconate, 3-hydroxyisovaleric acid } \\
\text { (UOA) }\end{array}$ & AUH \\
\hline $\begin{array}{l}\text { Pelizaeus-Merzbacher disease } \\
(\mathrm{PMD})^{32} 33\end{array}$ & $\begin{array}{l}\text { Usually infant-childhood } \\
\text { onset, case reports of adult } \\
\text { onset up to age } 45 \text { years }\end{array}$ & Limited case reports & & $\begin{array}{l}\text { X linked. } \\
\text { Heterozygote women } \\
\text { can develop spastic } \\
\text { paraparesis }\end{array}$ & & PLP1 \\
\hline $\begin{array}{l}\text { Recessive hypomyelinating } \\
\text { leukoencephalopathy (Pelizaeus- } \\
\text { Merzbacher-like disease) }^{34}\end{array}$ & $\begin{array}{l}\text { Case report of onset age } \\
15 \text { years }\end{array}$ & Case report & & AR & & $\begin{array}{l}\text { GJC2; } \\
\text { HSPD1; } \\
\text { AIMP1 }\end{array}$ \\
\hline $\begin{array}{l}\text { Leukoencephalopathy with brainstem } \\
\text { and spinal cord involvement and } \\
\text { lactate elevation }\end{array}$ & Usually childhood & Case report & & $A R$ & MRS: elevated lactate & DARS2 \\
\hline $\begin{array}{l}\text { Polycystic lipomembranous } \\
\text { osteodysplasia with sclerosing } \\
\text { leukoencephalopathy (Nasu-Hokola } \\
\text { disease) }\end{array}$ & $\begin{array}{l}\text { Mean } 30 \text { years (range } 10- \\
45 \text { years) }\end{array}$ & 33 cases in Japan & $\begin{array}{l}\text { Most reported cases in Finland } \\
\text { and Japan, but occur } \\
\text { worldwide }\end{array}$ & AR & Imaging of the hand & $\begin{array}{l}\text { TYROBP; } \\
\text { TREM2 }\end{array}$ \\
\hline Cockayne Syndrome $^{37}$ & $\begin{array}{l}\text { Usually infant/childhood. } \\
\text { reported adult cases age } \\
40 \text { and } 44 \text { years }\end{array}$ & $\begin{array}{l}\text { Overall } 1.8-2.7 \text { per million births. Four } \\
\text { cases reported with adult onset }\end{array}$ & $\begin{array}{l}\text { Canada (aboriginal residents of } \\
\text { Manitoba, Newfoundland), } \\
\text { Japan, Middle East and West } \\
\text { Asian countries }{ }^{35}\end{array}$ & AR & & $\begin{array}{l}\text { ERCC6; } \\
\text { ERCC8 }\end{array}$ \\
\hline
\end{tabular}

\section{The most frequently described adult onset inherited leukodystrophies.}

*Not traditionally classified as a classical leukodystrophy.

tARSA enzyme activity in leukocytes that is $5 \%-20 \%$ of normal controls may be caused by pseudodeficiency. Pseudodeficiency may be difficult to distinguish from true ARSA enzyme deficiency by biochemical testing alone. Therefore, the diagnosis of

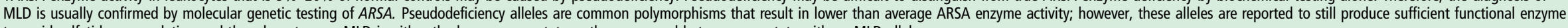

to avoid sulfatide accumulation and thus do not cause MLD in either the homozygous state or the compound heterozygous state with an MLD allele.

$A D$, autosomal dominant; AR, autosomal recessive; PLP, proteolipid protein. 
Table 2 Clinical features associated with adult onset leukodystrophies

\begin{tabular}{|c|c|}
\hline Suggestive presenting features & Leukodystrophy \\
\hline \multicolumn{2}{|l|}{ Visual involvement } \\
\hline Optic atrophy & Metachromatic leukodystrophy, Krabbe disease, mitochondrial disorders, Pelizaeus-Merzbacher disease \\
\hline Cortical blindness & Krabbe disease \\
\hline Retinal degeneration & Krabbe disease, mitochondrial disorders, Cockayne syndrome \\
\hline Cataracts & Cerebrotendinous xanthomatosis, mitochondrial disorders \\
\hline $\begin{array}{l}\text { Abnormal eye movements/ } \\
\text { nystagmus }\end{array}$ & Pelizaeus-Merzbacher disease, Pelizaeus-Merzbacher-like disease \\
\hline \multicolumn{2}{|l|}{ Neurological features } \\
\hline Peripheral neuropathy & $\begin{array}{l}\text { Metachromatic leukodystrophy (but often not seen in adult onset) } \\
\text { Cerebrotendinous xanthomatosis } \\
\text { Krabbe disease } \\
\text { Adult polyglucosan body disease }\end{array}$ \\
\hline Cerebellar ataxia & $\begin{array}{l}\text { Cerebrotendinous xanthomatosis } \\
\text { Alexander disease } \\
\text { Adult polyglucosan body disease } \\
\text { Vanishing white matter disease }\end{array}$ \\
\hline Psychiatric symptoms & $\begin{array}{l}\text { Metachromatic leukodystrophy } \\
\text { Vanishing white matter disease } \\
\text { Cerebral adrenoleukodystrophy } \\
\text { Hereditary diffuse leukoencephalopathy with axonal spheroids }\end{array}$ \\
\hline Pyramidal weakness/spasticity & $\begin{array}{l}\text { Adrenomyeloneuropathy/adrenoleukodystrophy } \\
\text { Krabbe disease } \\
\text { Cerebrotendinous xanthomatosis } \\
\text { Vanishing white matter disease } \\
\text { Adult polyglucosan body disease } \\
\text { Hereditary diffuse leukoencephalopathy with axonal spheroids }\end{array}$ \\
\hline $\begin{array}{l}\text { Bulbar dysfunction and palatal } \\
\text { myoclonus }\end{array}$ & Adult onset Alexander disease \\
\hline $\begin{array}{l}\text { Dystonic dyskinetic movement } \\
\text { disorder }\end{array}$ & Glutaricacidemia type 1 \\
\hline Autonomic features & Adult onset autosomal dominant leukodystrophy \\
\hline Migraine and stroke & CADASIL \\
\hline \multicolumn{2}{|l|}{ Other features } \\
\hline Primary/secondary amenorrhoea & Vanishing white matter disease \\
\hline Fractures following minor trauma & Polycystic lipomembranous osteodysplasia with sclerosing leukoencephalopathy (Nasu-Hokola disease) \\
\hline Macrocephaly & $\begin{array}{l}\text { Alexander disease, organic acidurias (Canavan disease, glutaricacidemia type 1, L-2-hydroxyglutaric aciduria), megalencephalic } \\
\text { leukoencephalopathy with subcortical cysts }\end{array}$ \\
\hline Tendon xanthoma & Cerebrotendinous xanthomatosis \\
\hline
\end{tabular}

\section{CASE DISCUSSION: ROUND 1 INVESTIGATIONS}

In this case, the phenotype was not one of relapsing-remitting MS, but a progressive deterioration, characterised by cognitive involvement over the previous 2 years. While progressive cognitive changes can occur in MS, the rapidity and severity are unusual. There also seems to be a possible dominant or maternal family history, which can occur in MS, but again uncommonly.

The following Round 1 investigations were normal or negative: full blood count, electrolytes, liver function tests; autoimmune and vasculitic screen. CSF examination revealed a mildly elevated protein of $0.58 \mathrm{~g} / \mathrm{L}$ (normal $<0.40 \mathrm{~g} / \mathrm{L}$ ), no white cells and was negative for oligoclonal bands $(<5 \%$ of cases of MS). ${ }^{38}$ Visual evoked potentials showed no abnormalities and nerve conduction studies were normal.

\section{What other information may be helpful in directing} investigations?

(A) Family history: This, if present, can be very informative (table 1). In establishing the inheritance pattern of a condition, the occurrence of sporadic cases, non-paternity, misdiagnosis in previous generations/other family members and a varied phenotypic presentation of the same disorder within a family should be considered.

(B) Ethnicity: The ethnic background of the patient may be helpful in focusing investigations (table 1). Conditions such as mucolipidosis, adult onset gangliosidosis and adult polyglucosan body disease are more common in the Ashkenazi Jewish population, whereas megalencephalic leukodystrophy with cysts is more common in those of Asian-Indian or Turkish ethnicity.

(C) Clinical presentation: Table 2 details particular clinical presentations that may point to a certain leukodystrophy. Absence of a feature does not however exclude a condition.

(D) MRI pattern: Specific changes on brain MRI can have diagnostic utility, but there is considerable overlap among disorders (table 3/figure 1). Table 3 details the MRI findings classically associated with the various leukodystrophies. Figure 1 illustrates the typical site of brain MRI changes for particular conditions. Figures 2 and 3 show brain MRI scans of adult patients with confirmed leukodystrophy. Additional information can be obtained from cervical imaging (eg, spinal cord atrophy seen in adult polyglucosan body disease) as well as cranial imaging and the use of contrast enhancement (eg, Alexander disease). Schiffmann and van der Knapp ${ }^{39}$ provide a diagnostic algorithm using MRI for the diagnosis of white matter disorders 
Table 3 Specific MRI findings in leukodystrophies

\begin{tabular}{|c|c|}
\hline MRI findings & Leukodystrophy \\
\hline \multicolumn{2}{|l|}{ Pattern of white matter involvement } \\
\hline Predominantly frontal periventricular & Metachromatic leukodystrophy, hereditary diffuse leukoencephalopathy with neuroaxonal spherods \\
\hline Predominantly parietal & Adult onset autosomal dominant leukodystrophy \\
\hline Predominantly periventricular & Adult polyglucosan body disease \\
\hline Predominantly posterior & Krabbe disease \\
\hline Predominantly occipital & X linked adrenoleukodystrophy \\
\hline $\begin{array}{l}\text { Posterior white matter changes progressing } \\
\text { anteriorly }\end{array}$ & X linked adrenoleukodystrophy \\
\hline Anterior temporal lobe changes & CADASIL, adult polyglucosan body disease (involvement of temporal lobe) \\
\hline Contrast enhancement & X linked adrenoleukodystrophy, Alexander disease \\
\hline Sparing of U fibres & Metachromatic leukodystrophy, cerebrotendinous xanthomatosis, adult polyglucosan body disease, Krabbe disease \\
\hline Involvement of $\mathbf{U}$ fibres & L-2-hydroxyglutaric aciduria \\
\hline \multicolumn{2}{|l|}{ Corpus callosum } \\
\hline Thinning & $\begin{array}{l}\text { Adult onset autosomal dominant leukodystrophy, vanishing white matter disease, hereditary diffuse leukoencephalopathy } \\
\text { with neuroaxonal spherods }\end{array}$ \\
\hline Hyperintensities & Hereditary diffuse leukoencephalopathy with neuroaxonal spherods, vanishing white matter disease \\
\hline Sparing & Cerebrotendinous xanthomatosis, adult polyglucosan body disease (atrophy of corpus callosum can develop late) \\
\hline \multicolumn{2}{|l|}{ Other findings } \\
\hline Enhancement of corticospinal tracts & Krabbe disease \\
\hline Cerebellar/brainstem white matter change & Adrenomyeloneuropathy, cerebrotendinous xanthomatosis, Alexander disease \\
\hline T2 hypointensity of dentate nucleus & Cerebrotendinous xanthomatosis, L-2-hydroxyglutaric aciduria \\
\hline $\begin{array}{l}\text { Atrophy medulla oblongata and upper } \\
\text { cervical cord }\end{array}$ & Alexander disease \\
\hline Spinal cord atrophy & Adult polyglucosan body disease, adrenomyeloneuropathy \\
\hline Cystic changes & Vanishing white matter disease, mitochondrial disease \\
\hline
\end{tabular}

that uses features such as the location of white matter change and the involvement of the peripheral nervous system to aid diagnosis.

Leukodystrophies and other white matter conditions can be misdiagnosed as MS. ${ }^{40}$ MRI white matter changes need to be examined closely for any 'red flags' that would not be consistent with a diagnosis of MS and may point towards another diagnosis. ${ }^{41}$ These have been suggested by the workshop of the European Magnetic Resonance Network in Multiple Sclerosis ${ }^{41}$ to alert clinicians based on imaging findings to consider another diagnosis. They include large lesions with mass effect, ring enhancement and symmetrically distributed lesions. Typically, findings in MS include: preferential involvement of the subcortical U fibres, the corpus callosum, temporal lobes, brainstem and cerebellum. Periventricular areas of T2 high signal are seen in $95 \%$ of patients, which may be scattered or confluent. Use of the McDonald 2010 criteria for the diagnosis of MS has been estimated to have an accuracy of $86 \%$ and specificity of $93 \%{ }^{42}$ In addition, spinal cord involvement may commonly be seen, unlike most genetic leukodystrophies, underscoring the value of cervical MRI. A rare differential diagnosis for MS is retinal vasculopathy with cerebral leukodystrophy, an autosomal dominant condition associated with pseudotumours on imaging, white matter lesions, visual changes and possible systemic findings. ${ }^{43}$

A common cause of white matter change is small vessel cerebrovascular disease. Leukodystrophies, as with the mother of this patient, may be diagnosed as vascular dementia. While small vessel ischaemia can cause very significant white matter change, red flags include: extensive changes in the absence of significant vascular risk factors and the absence of basal ganglia or brain stem involvement. Cerebral amyloid angiopathy can also lead to white matter changes; here, $\mathrm{T} 2 *$ or susceptibility weighted imaging can be helpful in demonstrating 'microbleeds' which are typically peripherally located. There have been reports of white matter change particularly involving the parieto-occipital regions in patients with duplication of the amyloid precursor protein. ${ }^{44}$ MRI changes of other differential diagnoses include the simultaneous enhancement of lesions and punctiform parenchymal involvement seen in sarcoidosis; mass effect and ring enhancement seen in abscesses; and bilateral non-progressive lesions at the grey-white matter junction in acute demyelinating encephalomyelitis.

\section{CASE DISCUSSION: FAMILY HISTORY, ETHNICITY, CLINICAL PHENOTYPE AND MRI PATTERN}

Returning to the case study and considering points (A)-(D) above, of particular note is the history of early onset dementia in the patient's mother, although definitive diagnostic information was lacking and there was no suggestion of other family members having been affected. Often the family history is censored or unclear. In this case, the history is consistent with maternal or dominant inheritance (A). From table 1, the four principal leukodystrophies associated with an autosomal dominant inheritance are: hereditary diffuse leukoencephalopathy with neuroaxonal spheroids (HDLS), cerebral autosomal dominant arteriopathy with subcortical infarcts and leukoencephalopathy (CADASIL), Alexander disease and adult onset autosomal dominant leukodystrophy (ADLD). The ethnicity provided no additional information (B). Our case had no features of migraine or stroke-like episodes to suggest CADASIL; no bulbar/ pseudobulbar involvement or morphological features (eg, macrocephaly) to suggest Alexander disease; and no autonomic involvement to suggest ADLD (C). The MRI (D), which showed 


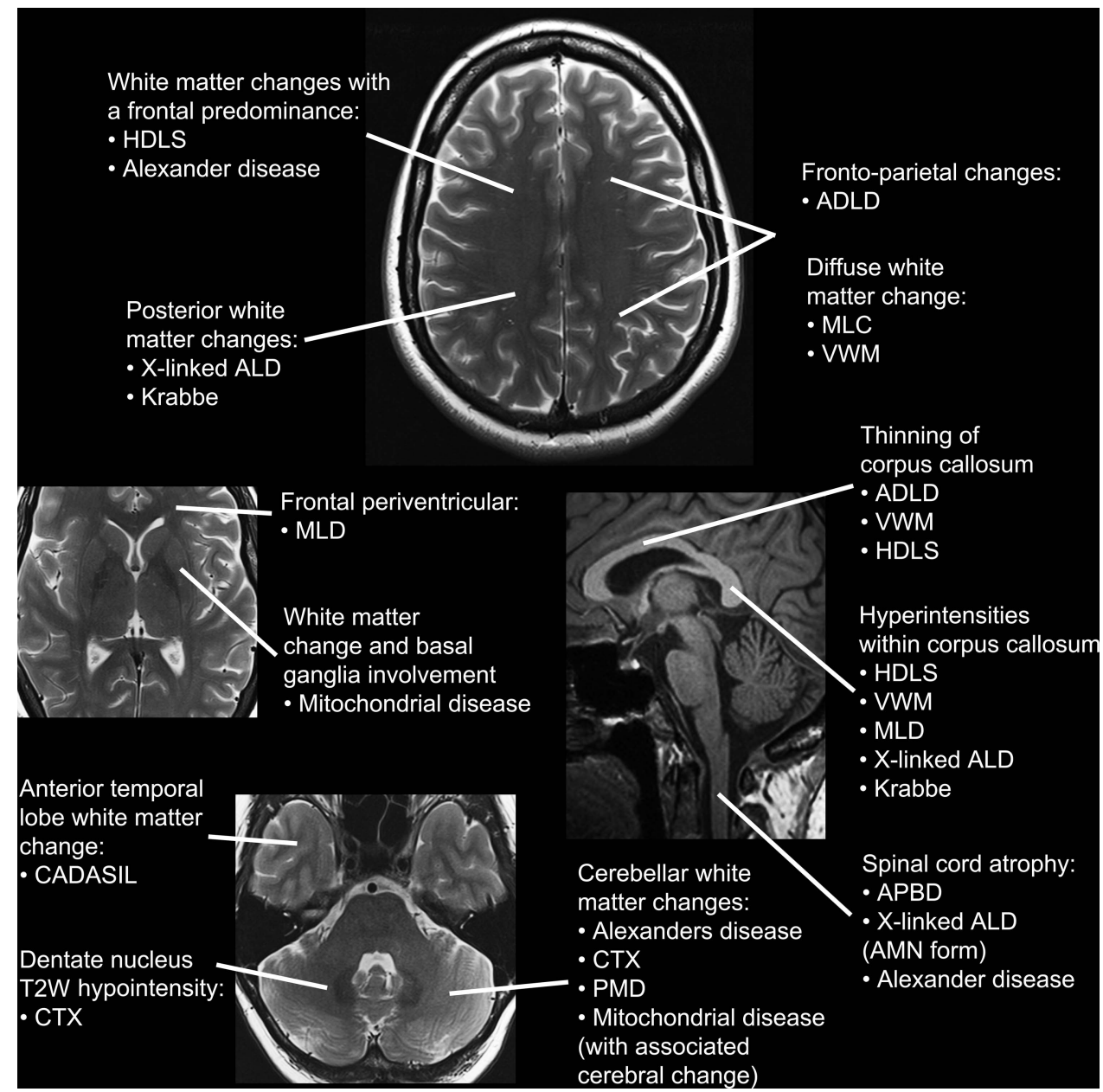

Figure 1 Schematic illustration of characteristic anatomical distribution of MRI abnormalities on normal MRI sequence panels, clockwise from the top: axial T2-weighted section at the level of the centra semiovale, midline sagittal T1-weighted section through the corpus callosum, brainstem and upper cervical spinal cord, axial T2-weighted section through the temporal poles, cerebellum and dentate nuclei and axial T2-weighted section through the basal ganglia.

widespread white matter change with a frontal predominance and atrophy of the corpus callosum, was most suggestive of HDLS or ADLD. Other leukodystrophies with frontal predominance (table 3) include metachromatic leukodystrophy (MLD); however, this has an autosomal recessive pattern of inheritance.

At this stage, it is appropriate to proceed to more specialist Round 2 investigations (table 4). From table 1 it can be seen that (fasting) very long chain fatty acid (VLCFA) levels, relevant white cell enzyme activities, cholestanol profile, urine bile alcohols and plasma amino acids should be measured as these will screen for the more common metabolic leukodystrophies. In particular, ALD has the highest prevalence at $40 /$ million apart from the combined mitochondrial disorders, and should be tested early. Before testing, it is advisable to contact the local specialist laboratory to discuss the type of sample required, the optimum timing of samples and the storage/transport conditions required to ensure integrity of the sample for testing.

In order to aid interpretation of the results, the laboratory should be informed of the age of the patient, the age of onset of the symptoms, and a summary of relevant clinical findings and family history. A list of concomitant medications should be given as these may influence some of the analytical measurements or modify metabolic processes.

\section{CASE DISCUSSION: ROUND 2 INVESTIGATIONS}

In our case, VLCFA and white cell enzyme activities were normal. Genetic testing for Alexander disease was negative. Over the next 12 months the patient continued to deteriorate. Discussions were held with the patient's family regarding the possibility of a brain biopsy, principally to exclude the remote chance of an inflammatory disorder, but this was declined. The patient was given a trial of oral steroids, but failed to improve. During this time, mutations in the colony stimulating factor 1 receptor (CSF1R) gene, responsible for HDLS, were identified. ${ }^{45}$ Sequence analysis of the patient's DNA subsequently identified a single mutation (E847D) in the CSF1R gene, confirming the diagnosis.

The flow diagram in online supplementary figure S2 summarises the investigative process. If no abnormalities are found on biochemical testing or if a diagnosis not known to be associated with any biochemical findings is suspected, then it may be appropriate to proceed to genetic testing. This may be by a single gene analysis or analysis of a panel of candidate genes, depending on clinical suspicion and/or resources. Some centres may also have access to next generation sequencing technologies such as whole exome sequencing, and it is likely that gene chips which can be designed to detect the genetic defects causing a range of different disorders in parallel, in a cost effective manner, will have a major impact on the diagnosis of these and related conditions. ${ }^{46}$ At time of writing, mutation analysis of the 

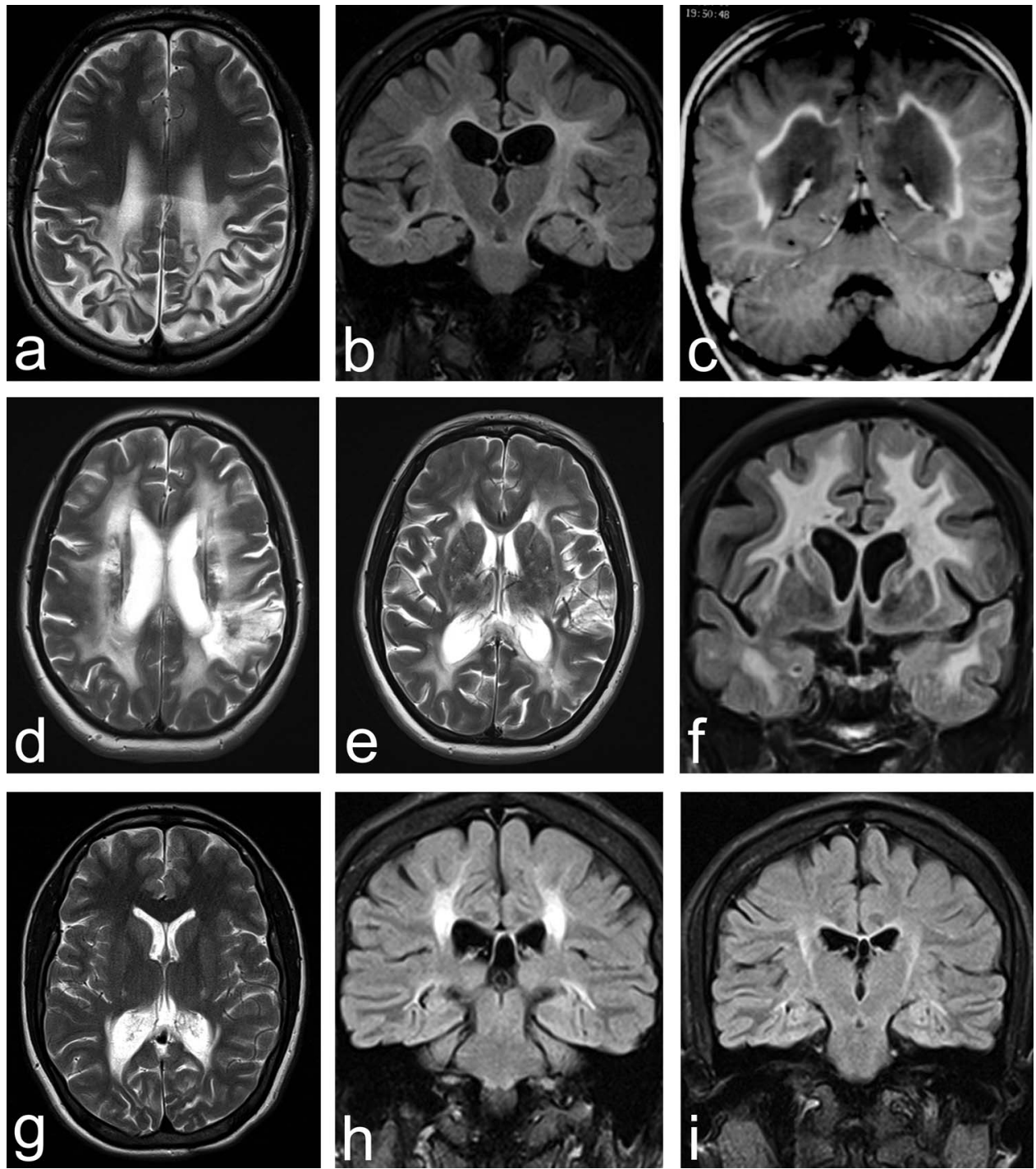

Figure 2 MRI brain acquisitions of: $X$ linked adrenoleukodystrophy on axial T2-weighted (a), coronal FLAIR (b) and coronal postgadolinium contrast (c) sequences showing diffuse white matter signal T2-weighted hyperintensity and volume loss of the posterior frontal, posterior callosal and parieto-occipital regions, extending along the corticospinal tracts through the internal capsules and temporal periventricular white matter. Peripheral enhancement of the parieto-occiptal confluent symmetrical signal abnormality is demonstrated. Cerebral autosomal dominant arteriopathy with subcortical infarcts and leukoencephalopathy on axial T2-weighted $(\mathrm{d}, \mathrm{e})$ and coronal FLAIR ( $\mathrm{f}$ ) sequences showing diffuse symmetrical white matter hyperintensity extending through the external capsules and temporal poles with multiple mature subcortical and a left superior parietal cortical infarcts. Krabbe disease (globoid cell leukodystrophy) on axial T2-weighted (g) and coronal FLAIR ( $\mathrm{h}$, i) sequences showing posterior periventricular and deep white matter hyperintensity and volume loss involving the corticospinal tracts and splenium of the corpus callosum.

following genes associated with leukodystrophies is available clinically (NHS) within the UK: ABCD1, ARSA, CSA, ERCC6, GALC, GBE1, GFAP, NOTCH3 and PLP1. Further details are available online (http://ukgtn.nhs.uk/). Diagnosis of mitochondrial disorders is coordinated via three specialist centres within the UK (http://www.mitochondrialncg.nhs.uk/).

\section{When should a brain biopsy be considered?}

A review of the seven most recent series in evaluating cryptogenic neurological diseases with brain biopsy estimated a yield rate between $29 \%$ and $65 \%{ }^{47}$ The rate was increased to $78 \%$ in the Gilkes $e a^{47}$ series, by biopsing a radiologically identified lesion, in particular with contrast enhancement. Biopsy not only helps in reaching a diagnosis, but can alter clinical management. Rice et $a l^{48}$ found that management was altered as a result of biopsy in $63 \%$ of their cases. The modern risk of stereotactic brain biopsy has been estimated at $10-20 \%,{ }^{49}$ with complications including seizures, intracranial infection and haemorrhage, but no long term neurological sequelae. Ideally a panel comprising a neurologist, neurosurgeon and neuroradiologist should discuss the optimal site for biopsy and ensure that the neuropathologist is aware of the clinical phenotype, imaging findings and family history to guide pathological evaluation. Algorithms have been suggested in the literature to aid decision making in presentations such as dementia ${ }^{49}$ and cryptogenic neurological conditions, ${ }^{47} 48$ but there are none specific to leukodystrophies. We feel that a biopsy in a suspected leukodystrophy should be considered under the following circumstances: the patient is deteriorating and a potentially treatable condition is being considered and/or all other investigations have failed to reach a diagnosis and it could aid in the management of other family members with or at risk of the condition. 

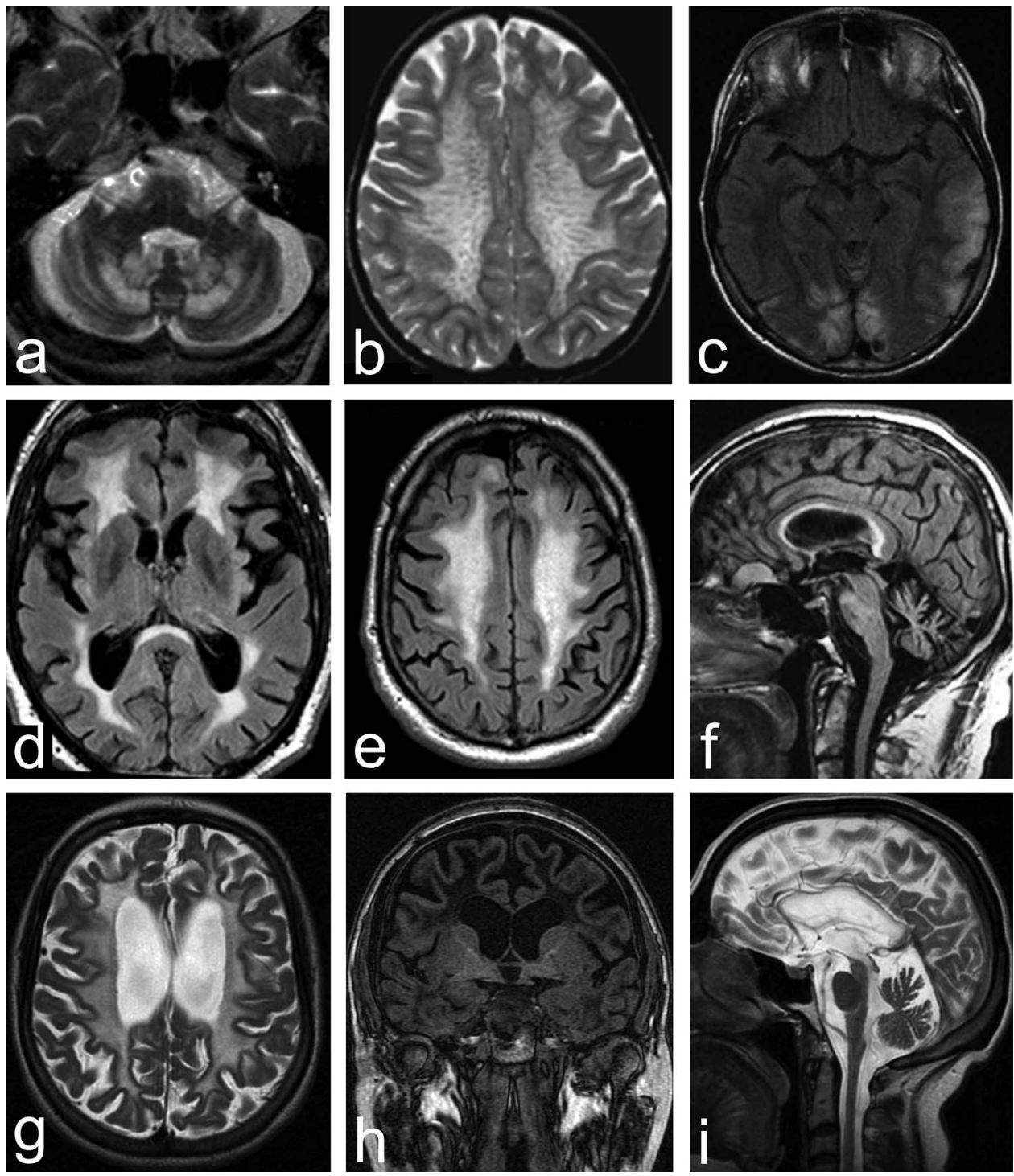

Figure 3 MRI brain acquisitions of: cerebrotendinous xanthomatosis on an axial T2-weighted sequence through the posterior fossa

(a) demonstrating white matter signal hypointensity involving the dentate nuclei and surrounding hyperintensity. Note the diffuse volume loss of the cerebellum disproportionate to the visible temporal poles. Metachromatic leukodystrophy on an axial T2-weighted sequence through the centra semiovale (b) demonstrating widespread symmetrical white matter signal hyperintensity sparing the subcortical U fibres and radiating transmedullary bands. Mitochondrial encephalopathy lactic acidosis and stroke-like episodes on an axial FLAIR sequence (c) demonstrating swelling and patchy hyperintensity of the cortical and subcortical matter of the occipital, right mesencephalic and left lateral temporal regions during an acute stroke-like episode. Adult polyglucosan body disease on an axial (d, e) and sagittal (f) FLAIR sequences demonstrating diffuse periventricular and inferior callosal white matter hyperintensity and volume loss. There is similarly cerebellar and spinal cord volume loss. An incidental planum sphenoidale meningioma is present. Vanishing white matter disease on axial and sagittal T2-weighted ( $\mathrm{g}$, i) as well as coronal T1-weighted (h) sequences demonstrating diffuse white matter T2-weighted hyperintensity and volume loss. Atrophy of the corpus callosum and spinal cord is also present.

\section{FREQUENTLY DIAGNOSED ADULT ONSET LEUKODYSTROPHIES}

We now summarise the clinical presentation and MRI findings for the most frequently diagnosed adult onset leukodystrophies and important non-classical leukodystrophies including CADASIL and mitochondrial conditions. A more detailed discussion of the complexities of mitochondrial disease is beyond the scope of this article, but a number of references are given. When considering a specific leukodystrophy, it should be noted that often the presentation can be non-specific, but certain symptoms and signs and MRI patterns can be used together to help formulate a differential diagnosis and aid investigation.

\section{X-linked adrenoleukodystrophy (X-ALD)}

Clinical presentation: Adult onset cerebral ALD usually presents with psychiatric features followed by dementia, ataxia, seizures and death. ${ }^{2}$ This may occur on the background of adrenomyeloneuropathy (AMN), a slowly progressive spastic paraparesis, neurogenic bladder and bowel dysfunction, sexual dysfunction and peripheral neuropathy. ${ }^{50}$ Adrenal insufficiency is frequently associated. About 20\% of female X linked ALD carriers develop symptoms, usually in their fourth decade, of an AMN-like phenotype, but only very rarely do they have adrenal insufficiency.

MRI features: White matter abnormalities are usually first seen in occipital regions, with early involvement of the splenium 
Table 4 More specialised Round 2 investigations

\begin{tabular}{|c|c|}
\hline Test & Comments \\
\hline \multicolumn{2}{|l|}{ Blood } \\
\hline Plasma amino acids & $\begin{array}{l}\text { Separate sample without delay and freeze for } \\
\text { transport or while awaiting analysis. Avoid } \\
\text { haemolysis }\end{array}$ \\
\hline $\begin{array}{l}\text { Very long chain fatty } \\
\text { acids }\end{array}$ & Preferably a preprandial or fasting sample \\
\hline $\begin{array}{l}\text { White cell (leukocyte) } \\
\text { enzyme activity }\end{array}$ & $\begin{array}{l}\text { Laboratories may group these tests according to } \\
\text { clinical features and so it is essential to provide } \\
\text { good clinical details and age of onset of symptoms. } \\
\text { A group of enzyme assays can be carried out on a } \\
\text { single blood sample which provides both white } \\
\text { blood cells and plasma for analysis. If a specific } \\
\text { enzyme deficiency is suspected then discuss with } \\
\text { your local enzyme laboratory in order to prioritise } \\
\text { particular assays. Some enzymes cannot be assayed } \\
\text { in leukocytes and skin fibroblasts will be required } \\
\text { instead. Depending on the clinical picture and other } \\
\text { biochemical results, the enzymes to be assayed } \\
\text { include: galactocerebosidase, arylsulfatase A, } \\
\beta \text {-hexosaminidase A, glycogen debrancher enzyme, } \\
\alpha \text {-mannosidase and aspartoacylase (table } 1 \text { ) }\end{array}$ \\
\hline \multicolumn{2}{|l|}{ Cholestanol profile } \\
\hline \multicolumn{2}{|l|}{ Urine } \\
\hline $\begin{array}{l}\text { Organic acids } \\
\text { Bile alcohols }\end{array}$ & $\begin{array}{l}\text { Random sample, with no preservatives, early } \\
\text { morning if possible as it is likely to be a more } \\
\text { concentrated sample. List all medications on the } \\
\text { request form to aid interpretation. Freeze sample fo } \\
\text { transport or prolonged storage }\end{array}$ \\
\hline \multicolumn{2}{|l|}{ Biopsy } \\
\hline Axillary skin biopsy & $\begin{array}{l}\text { Electron microscopy of biopsy helpful in the } \\
\text { diagnosis of CADASIL }\end{array}$ \\
\hline Sural nerve biopsy & $\begin{array}{l}\text { Can be useful in those leukodystrophies associated } \\
\text { with peripheral neuropathies, eg, in adult onset } \\
\text { polyglucosan body disease intra-axonal } \\
\text { polyglucosan bodies are seen. On electron } \\
\text { microscopy, these should be located within } \\
\text { mylinated nerves }\end{array}$ \\
\hline Muscle biopsy & See text for further information \\
\hline Brain biopsy & See text for further information \\
\hline
\end{tabular}

CADASIL, cerebral autosomal dominant arteriopathy with subcortical infarcts and leukoencephalopathy.

of the corpus callosum and posterior limbs of the internal capsule. ${ }^{50}$ The changes then progress to involve more anterior regions. In cerebral ALD, contrast enhancement at the periphery of the signal abnormalities is said to be characteristic. ${ }^{8}$ In AMN, the posterior limbs of the internal capsules are frequently involved along with cerebellar and brainstem white matter. ${ }^{51}$ Spinal cord atrophy may develop. Brain involvement on MRI is very rarely described in women with an ABCD1 mutation. A review of brain MRI imaging in 76 affected women found changes consistent with male patients with cerebral ALD in only two women. ${ }^{52}$ Although the authors attempted to exclude other known causes of leukodystrophy at the time, the possibility remains that these changes may in fact have been related to a second undiagnosed condition.

Cerebral autosomal dominant arteriopathy with subcortical infarcts and leukoencephalopathy (CADASIL)

Clinical presentation: Typically, patients present with migraine with a mean age at onset of 30 years; ${ }^{6}$ ischaemic events usually have their onset in the late 40s. As microvascular changes progress, patients develop cognitive and psychiatric symptoms and seizures.

MRI features: MRI changes usually precede the onset of other symptoms by $10-15$ years. The first changes are nodular white matter lesions in the periventricular areas and in the centrum semiovale. The abnormalities then typically become diffuse, symmetrical, and involve the external capsule and characteristically extend into the anterior temporal lobes to involve the temporal pole-a characteristic but not sensitive feature. ${ }^{6}$

\section{Krabbe disease}

Clinical presentation: The adult form (10\% of cases) typically presents with pyramidal tract dysfunction and spastic paraparesis. $^{53} 54$ Patients can also develop cognitive decline, seizures and cortical blindness. ${ }^{55}$ Approximately $20 \%$ of patients also have abnormal peripheral nerve electrophysiology, which shows slowing of conduction velocity. ${ }^{56}$

MRI features: Posterior predominant white matter changes, with sparing of the $U$ fibres and involvement of the splenium of the corpus callosum, are typically seen. A pattern of radiating stripes of normal signal intensity is seen in the cerebral white matter. ${ }^{57} \mathrm{~T} 2$ hyperintense changes are seen along the corticospinal tracts ${ }^{58}$ and the posterior limb of the internal capsule and the pyramidal tracts of the brainstem. On CT, hyperintensities are seen in the thalamus and basal ganglia; it is unclear what these hyperintensities on CT represent, but it has been suggested they may represent minute calcifications.

\section{Cerebrotendinous xanthomatosis (CTX)}

Clinical presentation: Typically, patients will present in adolescence with cataracts, but then in adulthood will go onto develop a spastic paraparesis, pyramidal tract signs, cerebellar ataxia, bulbar symptoms and peripheral neuropathy. There may be a childhood history of diarrhoea or failure to thrive. If left untreated, patients can develop progressive dementia and psychiatric symptoms. ${ }^{59}$ Patients should be examined for other organ involvement including tendon xanthomata (usually involving the Achilles tendon), osteoporosis, ${ }^{60}$ and respiratory, endocrine and liver involvement. ${ }^{61}$

MRI features: Non-specific supratentorial atrophy and deep periventricular white matter change can be seen. The $U$ fibres and corpus callosum are spared. The classic picture is high signal intensity within the cerebellar white matter and low signal intensity in the dentate nucleus on T2-weighted imaging. 57

\section{Metachromatic leukodystrophy (MLD)}

Clinical presentation: The adult form accounts for approximately $20 \%$ of MLD presentations. ${ }^{2}$ The initial symptoms are often psychiatric, followed later by the onset of motor symptoms including spastic paraparesis and cerebellar ataxia, ${ }^{62}$ and then intellectual and cognitive decline. ${ }^{63}$ Other neurological signs include optic atrophy and dystonia, a demyelinating peripheral neuropathy ${ }^{62}$ and late in the disease, seizures. ${ }^{62}$

MRI features: These include widespread symmetrical confluent white matter change with a periventricular, frontal predominance. Typically there is a (tigroid) pattern of radiating stripes in the affected white matter. The subcortical $U$ fibres are typically spared. Typically, the corpus callosum is involved early. ${ }^{57}$

\section{Mitochondrial disorders}

White matter involvement is increasingly recognised as a common finding in mitochondrial disorders, both those associated with alterations in mitochondrial DNA, which include 
Leigh disease, Kearns Sayer syndrome, mitochondrial encephalopathy lactic acidosis and stroke-like episodes, mitochondrial neurogastrointestinal encephalomyopathy and Leber's hereditary optic neuropathy, as well as those associated with mutations in nuclear DNA (typically in genes of DNA repair proteins), which are transmitted in a Mendelian pattern. While not traditionally classified as a leukodystrophy, these disorders form an important aspect of the differential diagnosis in this context.

Clinical presentation: Clinical presentation can occur at any stage of life, and many of these disorders have characteristic features, although most present with multi-system involvement. ${ }^{64}$ Although mitochondrial DNA is inherited by a maternal pattern, no family history may be present, new mutations may arise or heteroplasmy (the variation of mitochondria in the same organism) may result in a higher proportion of mutant mitochondrial DNA in one individual compared with the mother (or siblings inheriting the same mutation), such that the disease manifests earlier or with a different phenotype. Interpretation of the inheritance pattern is made even more difficult by disorders that result from mutations in nuclear DNA.

MRI features: In each of the specific mitochondrial disorders, specific white matter patterns have been described. Lerman-Sagie et $a l^{65}$ provide a useful review of the different white matter patterns in specific disorders. MRI findings suggestive of a mitochondrial disorder include small cyst-like lesions within the abnormal white matter, involvement of both cerebral and cerebellar white matter, and the combination of both white matter change and bilateral basal ganglia lesions. ${ }^{65}$

Genetic testing: The diagnosis of a mitochondrial disorder involves clinical suspicion, laboratory testing and the use of these results to direct genetic testing. In the first instance, the clinical phenotype should be defined using history, examination, neuroimaging, neurophysiology, audiometry and cardiology and ophthalmological opinion and investigation. Blood tests measuring lactate and cerebrospinal fluid (CSF) examination should also be performed. The next crucial step is a muscle biopsy for which histochemical studies and biochemical analysis of mitochondrial respiratory chain complexes can be performed. These results can then direct the genetic sequencing analyses performed. McFarland et $a l^{64}$ provide a comprehensive overview and algorithm for genetic testing in mitochondrial disorders.

\section{Hereditary diffuse leukoencephalopathy with neuroaxonal} spheroids (HDLS)

Clinical presentation: Patients typically present in adulthood, with personality change, and cognitive impairment, particularly executive dysfunction and memory problems. ${ }^{66}$ Patients then go on to develop spasticity, gait problems (these may be an early feature), ataxia and urinary incontinence.

MRI features: Typically, patients have non-enhancing, symmetrical white matter T2 hyperintensity with a frontal predominance also involving the precentral and postcentral gyrus, extending from the periventricular and deep regions to subcortical tissues. There may be associated atrophy in the regions of hyperintensity and abnormal signal in the corpus callosum with or without atrophy. ${ }^{67}$ The signal abnormalities extend downwards through the posterior limb of the internal capsule into the pyramidal tracts of the brainstem. ${ }^{57}$

\section{Adult polyglucosan body disease (APBD)}

Clinical presentation: Patients present with a mixed picture of spastic paraparesis, but also have signs of lower motor neurone involvement, and bladder dysfunction. They can also have cognitive impairment, ataxia and extra-pyramidal signs.
MRI features: MRI typically shows diffuse periventricular white matter change involving predominantly the occipital and temporal lobes and the mesencephalon and cerebellum. The white matter changes are most prominent in the periventricular region, posterior limb of the internal capsule and external capsule and spare the $U$ fibres and corpus callosum. In the later stages, thinning of the corpus callosum can develop. There is diffuse cerebral, cerebellar and spinal cord atrophy. ${ }^{68} 69$

\section{Alexander disease}

Clinical presentation: In a review of the adult cases reported in the literature (36 cases), ${ }^{17}$ the most common presentation was with bulbar dysfunction, pyramidal involvement, cerebellar ataxia and sleep abnormalities. Palatal myoclonus, urinary abnormalities and autonomic dysfunction have also been reported.

MRI features: In adult onset disease, there is typically white matter change and atrophy within the medulla oblongata and upper cervical spinal cord. There can be mild to moderate periventricular white matter change, but this is not present in all cases. Other signs suggestive include hyperintensities on T2-weighted images and postcontrast enhancement particularly in patients aged less than 40 years. ${ }^{70}$ The MRI findings in adult onset Alexander disease differ from those in the infantile/juvenile form which include: extensive white matter change with frontal predominance, a periventricular rim with high signal on T1-weighted images and low signal on T2-weighted images, abnormalities of the basal ganglia and thalami, brainstem abnormalities and contrast enhancement. ${ }^{71}$

Adult onset autosomal dominant leukodystrophy (ADLD)

Clinical presentation: Typically, patients present in the fourth or fifth decade with autonomic abnormalities, followed by pyramidal symptoms, ataxia and cognitive deterioration. ${ }^{19}$

MRI features: Diffuse white matter T2 hyperintensities involving the frontal lobe, parietal lobe and middle cerebellar peduncle. There is atrophy of the brainstem and corpus callosum.

\section{Vanishing white matter disease (VWM)}

Clinical presentation: At least 25 adult onset cases have been described in the literature. ${ }^{20}$ Features include spasticity, cerebellar signs, seizures and dementia. A third of patients presented with psychiatric symptoms. ${ }^{20}$ Female patients can also present with primary or secondary ovarian failure.

MRI features: MRI changes are characterised by diffuse T2 hyperintensity and hypointensity with associated cystic change (seen on FLAIR imaging) and atrophy. There is also corpus callosal atrophy and T2 and flair hyperintensities. Atrophy of the cerebellar hemispheres has also been reported, both with and without associated white matter changes. ${ }^{20}$ In end stage, vanishing white matter disease cerebral hemispheric white matter may have vanished leaving a ventricular wall and cortex, with little in between. ${ }^{57}$

\section{Pelizaeus-Merzbacher disease (PMD) and Pelizaeus-Merzbacher-like disease}

There are limited case reports in adults; however, PelizaeusMerzbacher disease (PMD) is often on the differential diagnosis list due to the common presentation of spastic paraplegia.

Clinical features: The adult type may present with a chronic neurological syndrome including tremor, ataxia and dementia. ${ }^{32}$ Heterozygote females are usually asymptomatic, but can present with gait abnormalities. There are reports of heterozygote females in their 40s developing clumsiness, excessive falling and gait disturbances (wide based gait), hyper-reflexia, tremor and 
extensor plantar responses. ${ }^{72}$ Hereditary spastic paraplegia type 2 is clinically distinct from PMD, but is also due to mutations in the proteolipid protein (PLP) gene. Pelizaeus-Merzbacher-like disease is clinically indistinct from PMD; however, patients are negative for the PLP mutation.

MRI features: Varying MRI patterns have been reported including diffuse white matter change, both with and without involvement of the corticospinal tracts, and patchy changes involving the cerebral hemispheres. ${ }^{73}$

This review highlights that there are a wide range of leukodystrophies. ${ }^{57}$ New genetic findings are being identified with advanced techniques, but many are as yet undiagnosable in life. $\mathrm{OMIM}^{74}$ is a useful resource for newly characterised leukodystrophies.

\section{ARE THERE ANY SPECIFIC TREATMENTS FOR ADULT ONSET LEUKODYSTROPHIES?}

Support is required for patients and families during the process of making a diagnosis and once it is made. Due to the late onset, many affected patients have already had their own children, and detailed genetic counselling is required to explain the full implications of a particular diagnosis.

The treatment of the leukodystrophies in adulthood is largely supportive. Even if specific treatment is available, by the time a diagnosis is made the condition in many adults may be very advanced. For example, chenodeoxycholic acid has been used as therapy for cerebrotendinous xanthomatosis since 1975. However, after significant neurological disease is established, the effect of treatment is limited and deterioration may continue. ${ }^{75} 76$

Nonetheless, this is a very active area of research and a number of clinical trials are currently underway worldwide. These include haematopoietic stem cell transplant (ALD, MLD, Krabbe disease, Tay-Sachs disease), human placental-derived stem cell transplant (ALD, MLD, Krabbe disease), intrathecal enzyme replacement therapy (MLD), intracerebral gene therapy (MLD), haematopoietic stem cell gene therapy (MLD), allogeneic bone marrow transplant (ALD, MLD, Krabbe disease) and autologous haematopoietic stem cell transplant transduced with ABCD1 lentiviral vector (ALD). Further details can be found on http://www.clinicaltrials.gov, but it must be noted that not all studies are recruiting adult patients.

\section{CONCLUSIONS}

Adult onset leukodystrophies represent a highly complex area of adult neurology, compounded by their rarity, with a total prevalence of 300 cases/million. There is a wealth of information on paediatric leukodystrophies, but adult onset cases can be misdiagnosed as atypical MS or young onset vascular or neurodegenerative dementia. ${ }^{66}$ In this overview, our aim is to describe a logical approach to the diagnostic process, reducing unnecessary (and expensive) investigations and using selectively the newer genetic advances.

\section{DATA SHARING STATEMENT}

The authors would be happy to be contacted to discuss or see patients with possible adult onset leukodystrophies.

\section{Author affiliations}

${ }^{1}$ Department of Neurodegenerative Disease, Dementia Research Centre, National Hospital for Neurology \& Neurosurgery and UCL Institute of Neurology, London, UK ${ }^{2}$ The Charles Dent Metabolic Unit, National Hospital for Neurology \& Neurosurgery and UCL Institute of Neurology, London, UK

${ }^{3}$ Lysholm Department of Neuroradiology, National Hospital for Neurology \& Neurosurgery and Brain Repair and Rehabilitation unit UCL Institute of Neurology, London, UK
}

${ }^{4}$ Queen Square Centre for Neuromuscular Diseases, National Hospital for Neurology \& Neurosurgery and UCL Institute of Neurology, London, UK

${ }^{5}$ Department of Molecular Neurosciences, National Hospital for Neurology \& Neurosurgery and UCL Institute of Neurology, London, UK

${ }^{6}$ Department of Neuroinflammation, Queen Square Multiple Sclerosis Centre, National Hospital for Neurology \& Neurosurgery and UCL Institute of Neurology, London, UK

Acknowledgements The authors would like to acknowledge the UK National Institute of Health Research (NIHR) University College London Hospitals Biomedical Research Centres funding scheme, the NIHR Queen Square Dementia Biomedical Research Unit, The Medical research council (MRC) and Wellcome Trust. The Dementia Research Centre is supported by Alzheimer's Research UK, the Brain Research Trust and the Wolfson Foundation.

Contributors RA, NF, JC: manuscript concept, manuscript writing and preparation; EM: manuscript writing and preparation; ID: manuscript writing and preparation, figure preparation and radiological input; MP, JS, CM, RL, HH, JR: manuscript writing and preparation.

\section{Competing interests None.}

Provenance and peer review Commissioned; externally peer reviewed.

\section{REFERENCES}

1 Renaud DL. Clinical approach to leukoencephalopathies. Semin Neurol 2012;32:29-33.

2 Costello DJ, Eichler AF, Eichler FS. Leukodystrophies: classification, diagnosis and treatment. Neurologist 2009;15:319-28.

3 Maria BL, Deidrick KM, Moser H, et al. Leukodystrophies: pathogenesis, diagnosis, strategies, therapies, and future research directions. J Child Neurol 2003; 18:578-90.

4 Moser HW, Mahmood A, Raymond GVC. X linked adrenoleukodystrophy. Nat Clin Pract Neurol 2007:3:140-51.

5 Van Geel BM, Beman L, Loes DJ, et al. Evolution of phenotypes in adult male patients with x-linked adrenoleukodystrophy. Ann Neurol 2001;49:186-94.

6 Narayan SK, Gorman G, Kalaria RN, et al. The minimum prevalence of CADASIL in northeast England. Neurology 2012;78:1025-7.

7 Chabriat H, Joutel A, Dichgans M, et al. CADASIL. Lancet Neurol 2009;8:643-53.

8 Sedel F, Tourbah A, Fontaine B, et al. Leukoencephalopathies associated with in born errors of metabolism in adults. J inherit metab dis 2008;31:295-307.

9 Wenger DA, Suzuki K, Suzuki Y, et al. Galaclosylceramide lipidosis globoid cell leukodystrophy (Krabbe disease). In: Scriver CR, Beaudet AL, Sly WS, et al., eds. The Metabolic and molecular bases of inherited disease. 8th edn. New York: McGraw Hill 2001:3669-94.

10 Heinisch U, Zlotogora J, Kafert S, et al. Multiple mutations are responsible for the high frequency of metochromatic leukodystrophy in a small geographic area. Am J Hum genet 1995;56:51-7

11 Lorincz MT, Rainer S, Thomas D, et al. Cerebrotendinous xanthomatosis, possible higher prevalence than previously recognized. Arch Neurol 2005;62:1459-63.

12 Garone C, Tadesse S, Hirano M. Clinical and genetic spectrum of mitochondrial neurogastrointestinal encephalomyopathy. Brain 2011;134:3326-32.

13 Schaefer AM, McFarland R, Blakely EL, et al. Prevalence of mitochondrial DNA disease in adults. Ann Neurol 2008:63:35-9.

14 Wong LJC. Mitochondrial syndromes with leukoencephalopathies. Semin Neurol 2012;32:55-61.

15 Wong JC, Chow TW, Hazrati LN. Adult onset leukoencephalopathy with axonal spheroids and pigmented glia can present as frontotemporal dementia syndrome. Dement geriatr cogn disord 2011;32:150-8.

16 Savage G, Ray F, Halmagyi M, et al. Stable neuropsychological deficits in adult polyglucosan body disease. J Clin Neurosci 2007;14:473-7.

17 Pareyson D, Fancellu R, Mariotti $C$, et al. Adult onset Alexander disease: a series of 11 unrelated cases with review of the literature. Brain 2008;131:2321-31.

18 Tillema JM, Renaud DL. Leukoencephalopathies in adulthood. Semin Neurol 2012;32:85-94.

19 Melberg A, Hallberg C, Kalimo H, et al. MR characteristics and neuropathology in adult onset autosomal dominant leukodystrophy with autonomic symptoms. AJNR Am J Neuroradiol 2006;27:904-11.

20 Labauge $\mathrm{P}$, Horzinski $\mathrm{L}$, Ayrignac $\mathrm{X}$, et al. Natural history of adult onset elF2B related disoders: a multi centric survey of 16 cases. Brain 2009;132:2162-9.

21 Fukutake T. Cerebral autosomal recessive arteriopathy with subcortical infarcts and leukoencephalopathy (CARASIL): from discovery to gene identification. J Stroke Cerebrovasc Dis 2011;20:85-93.

22 MaGueen GM, Rosebush PI, Mazurek MF. Neuropsychiatric aspects of the adult variant of Tay Sachs disease. J Neuropsychiatry Clin Neurosci 1998;10:10-19.

23 Blattner R, Van Moers A, Leegwater PAJ, et al. Clinical and genetic heterogeneity in megalencephalic leukoencephalopathy with subcortical cysts. Neuropediatrics 2003:34:215-18. 
24 Birnbaum T, Blam HJ, Prokisch $\mathrm{H}$, et al. Methylenetetrahydrofolate reductase deficiency (homocystiuria type II) as a rare cause of rapidly progressive tetraspasticity and psychosis in a previously healthy adult. J Neurol 2008;255:1845-6.

25 Gutschalk A, Harting I, Cantz M, et al. Adult alpha mannosidosis. Clinical progression in the absence of demyelination. Neurology 2004;63:1744-6.

26 Reis S, Sheffer RN, Merin S, et al. Mucolipidosis type IV; a mild form with late onset. Am J med genet 1993;47:392-4.

27 Varho $T$, Jaaskelainen $S$, Tolonen $U$, et al. Central and peripheral nervous system dysfunction in the clinical variation of Salla disease. Neurology 2000;55:99-104.

28 Kulkens S, Harting I, Sauer $\mathrm{S}$, et al. Late onset neurologic disease in glutaryl- CoA dehydrogenase deficiency. Neurology 2005;64:2142-4.

29 Owens WE, Okun MS. Dystonia, tremor, and parkinsonism in a 54-year-old man with 2- hydroxyglutaric aciduria. J Neurol Neurosurg Psychiatry 2004;75:1362-3.

30 Eriguchi M, Mizuta $\mathrm{H}$, Kurohara K, et al. 3-methylglutaconic aciduria type 1 causes leukoencephalopathy of adult onset. Neurology 2006;67:1895-6.

31 Bischof F, Nagele T, Wanders RJ, et al. 3 Hydroxy 3- methylglutaryl CoA lyse deficiency in an adult with leukoencephalopathy. Ann Neurol 2004;56:727-30.

32 Sasaki A, Miyanaga K, Ototsuji M, et al. Two autopsy cases with PelizaeusMerzbacher disease phenotype of adult onset, without mutation of proteolipid protein gene. Acta Neuropathol 2000;99:7-13

33 Warshawsky I, Rodick RA, Staugaitis SM, et al. Primary progressive multiple sclerosis as a phenotype of PLP1 gene mutation. Ann Neurol 2005;58:470-3.

34 Nezu A, Kimura S, Uehara $S$, et al. Pelizaeus- Merzbacher like disease: female case report. Rain dev 1996;18:114-18.

35 Tzoulis C, Tran GT, Gjerde IO, et al. Leukoencephalopathy with brainstem and spinal ord involvement caused by a novel mutation in the DARS2 gene. J Neurol 2012;259:292-6

36 Kaneko M, Sano K, Nakayama J, et al. Nasu- Hokola disease: the first case reported by Nasu and review. Neuropathology 2010;30:463-70.

37 Natale V. A comprehensive description of the severity groups in cockayne syndrome. Am J Med Genet 2011;155:1081-95.

38 Lourenco P, Shirani A, Saeedi J, et al. Oligoclonal bands and cerebrospinal fluid markers in multiple sclerosis: associations with disease course and progression. Mult Scler 2013:19:577-84.

39 Schiffmann R, van der Knapp MS. An MRI based approach to the diagnosis of white matter disorders. Neurology 2009:72:750-9.

40 Kohler W. Diagnostic algorithm for the differentiation of leukodystrophies in early MS. J Neurol 2008:255:123-6.

41 Charil A, Yousry TA, Rovaris M, et al. MRI and the diagnosis of multiple sclerosis: expanding the concept of "no better explanation". Lancet Neuol 2006;5:841-52.

42 Runia TF, Jafar N, Hintzen RQ. Application of the 2010 revised criteria fort he diagnosis of multiple sclerosis to patients with clinically isolated syndrome. Eur J Neurol 2013. epub ahead of print.

43 Hardy TA, Chataway J. Tumefactive demyelination: an approach to diagnosis and management. J Neurol Neurosurg Psychiatry 2013:84:1047-53.

44 Cabrejo L, Guyant-Marechal L, Laquerriere A, et al. Phenotype associated with APP duplication in five families. Brain 2006:129:2966-76.

45 Rademakers R, Baker M, Nicholson AM, et al. Mutations in the colony stimulating factor 1 receptor (CSF1R) gene cause hereditary diffuse leukoencephalopathy with spheroids. Nat Genet 2012;44:200-5.

46 Beck J, Pittman A, Adamson G, et al. Validation of next-generation sequencing technologies in genetic diagnosis of dementia. Neurobiol Aging 2014;35;261-5.

47 Gilkes CE, Love S, Hardie RJ, et al. Brain biopsy in benign neurological disease J Neurol 2012:259:995-1000.

48 Rice CM, Gilkes CE, Teare E, et al. Brain biopsy in cryptogenic neurological disease. British J Neurosurg 2011;25:614-20.

49 Schott JM, Reineiger L, Thom M, et al. Brain biopsy in dementia: clinical indications and diagnostic approach. Acta Neuropathol 2010;120:327-41.

50 Moser HW. Adrenoleukodystrophy: phenotype, genetics, pathogenesis and therapy. Brain 1997:120:1485-508.

51 Patay Z. Diffusion weighted MR imaging in leukodystrophies. Eur Radiol 2005; 15:2284-303
52 Fatema A, Barker PB, Ulug AM, et al. MRI and proton MRSI in women heterozygote for adrenoleukodystrophy. Neurology 2003;60:1301-7.

53 Wegner DA, Rafi MA, Luzi P. Molecular genetics of Krabbe disease (globoid cells=leukodystrophy): diagnostic and clinical implications. Hum Mutat 1997:10:268-79.

54 Barone R, Bruhl K, Stoeter P, et al. Clinical and neuroradiological findings in classic infantile and late onset globoid- cell leukodystrophy (Krabbe disease). Am J Med Genet 1996:63:209-17.

55 Wenger DA, Rafi MA, Luzi $\mathrm{P}$, et al. Krabbe disease: genetic aspects and progress towards therapy. Mol Genet Metab 2000;70:1-9.

56 Husain AM, Altuwaijri M, Aldosari M. Krabbe disease: neurophysiologic studies and MRI correlations. Neurology 2004;63:617-20.

57 Van der Knapp MS, Valk J. eds Magnetic resonance of Myelination and Myelin Disorders. 3rd ed. Berlin: Springer, 2005

58 Farina L, Bizzi A, Finocchiaro G, et al. MR imaging and proton MR spectroscopy in adult krabbe disease. AJNR Am J Neuroradiol 2000;21:1478-82.

59 Federico A, Dotti MT. Cerebrotendinous xanthomatosis: clinical manifestations, diagnostic criteria, pathogenesis and therapy. J Child Neurol 2003, 18:633-8.

60 Federico A, Dotti MT, Lore Nutti R. Cerebrotendinous xanthomatosis: pathophysiological study on bone metabolism. J Neurol Sci 1993;115:67-70.

61 Verrips A, Hoefsloot LH, Steenbergen GC, et al. Clinical and molecular genetic characteristics of patients with cerebrotendinous xanthomatosis. Brain 2000;123:908-19.

62 Hageman AT, Gabreels FJ, De Jong JG, et al. Clinical symptoms of adult metachromatic leukodystrophy and arylsulfatase A pseudodeficiency. Arch Neurol 1995;52:408-13.

63 Mahmood A, Berry J, Wenger DA, et al. Metachromatic leukodystrophy: a case of triplets with the late infantile variant and a systematic review of the literature. J Child Neurol 2010;25:572-80.

64 McFarland R, Taylor RW, Turnbull DM. A neurological perspective on mitochondrial disease. Lancet Neurol 2010;9:829-40.

65 Lerman-Sagie T, Leshinsky-Silver $E$, Watemberg $N$, et al. White matter involvement in mitochondrial diseases. Mol Genet Metab 2005:84:127-36.

66 Sundal S, Lash J, Aasly J, et al. Hereditary diffuse leukoencephalopathy with axonal spheroids (HDLS): a misdiagnosed disease entity. J Neuro/ Sci 2012; 314:130-7

67 Sundal C, Van Gerpen JA, Nicholson A, et al. MRI characteristics and scoring in HDLS due to CSF1R gene mutation. Neurology 2012;79:566-74.

68 Ziemssen F, Sindern E, Schroder JM, et al. Novel missense mutations in the glycogen branching enzyme gene in adult polyglucosan body disease. Ann Neurol 2000;47:536-40.

69 Mochel F, Schiffmann R, Steenweg ME. Adult Polyglucosan body disease. Natura history and key magnetic resonance imaging findings. Ann Neurol 2012;72:433-41

70 Farina L, Pareyson D, Minati L, et al. Can MR imaging diagnose adult onset alexander disease. AJNR Am J Neuroradiol 2008:29:1190-6.

71 Van der Knaap MS, Naidu S, Breiter SN, et al. Alexander disease: diagnosis with MR imaging. AJNR Am J Neuroradiol 2001;22:541-52.

72 Marble M, Voeller KS, May MM, et al. Pelizaeus-Merzbacher syndrome: neurocognitive function in a family with carrier manifestations. Am J Med Genet 2007:143A:1442-7.

73 Nezu A, Kimura S, Takeshita S, et al. An MRI and MRS Study of Pelizaeus-Merzbacher Disease. Paediatr Neurol 1998:18:334-7.

74 Online Mendelian Inheritance in Man, OMIM®. Baltimore, MD: McKusick-Nathans Institute of Genetic Medicine, Johns Hopkins University, 2013. http://omim.org/

75 Donaghy M, King RH, Mckeran RO, et al. Cerebrotendinous xanthomatosis: clinical, electrophysiological and nerve biopsy findings, and response to treatment with chenodeoxycholic acid. J Neurol 1990;237:216-19.

76 Yahalom G, Tsabari R, Molshatzki N, et al. Neurological outcome in cerebrotendinous xanthomatosis treated with chenodeoxycholic acid: early versus late diagnosis. Clin Neuropharmacol 2013;36:78-83. 